\section{Development of a Year-round Student Organic Farm and Organic Farming Curriculum at Michigan State University}

\author{
John A. Biernbaum ${ }^{1,3}$, Laurie Thorp ${ }^{2}$, and Mathieu Ngouajio ${ }^{1}$
}

ADDITIONAL INDEX WORDS. community supported agriculture, experiential undergraduate education, organic curricula

Summary. How do you teach community supported agriculture (CSA) principles, small-scale organic farming, and local food issues at a major land grant university and develop related small-scale farming research and outreach? You create a place and opportunities for students, staff, and faculty to work together with the soil and plants to raise food in a non-classroom farm setting. After several years of discussion and obtaining funding, the Michigan State University (MSU) Student Organic Farm (SOF) CSA started in May 2003 with 25 memberships and increased to 50 after 1 year. The farm allows experiential learning of CSA management, crop selection, scheduling, maintenance, harvest, and organic farming methods. The CSA helps many MSU students and faculty see the value of supporting local organic food systems. With more than 3 years of experience working with students to run the SOF and the CSA, we are in the process of developing an organic farming certificate program. A total of 40 credits will include 12 months on campus plus a 16-week on-farm internship. The program has three major components: 1) organic farming courses with seven one-credit courses; 2) horticultural crop production courses with eight courses for a total of 15 credits; and 3 ) approximately 20 credits of experiential course work combined with classroom and independent learning.

$\mathrm{E}$ nrollment of students in traditional agricultural programs has been declining steadily since the early 1990s (Bradley et al., 2003; Dyer et al., 1996, 1999; Newcomb, 1993). This trend has been associated with many factors, including lack of early involvement of students in an agricultural curriculum (Dyer et al., 1996, 1999) and, more importantly, student demand for alternative curricula, especially in sustainable and organic agriculture (Sayre, 2004). With the increasing interest of students, the general public, and policy makers in organic agriculture, novel approaches to instruction in this area need to be developed and implemented. Horticulture students are increasingly demanding more active learning (St. Hilaire and Thompson, 2005). Therefore, experiential learning should be emphasized in new organic and sustainable agriculture curricula.

This report is one of 10 presentations in a workshop sponsored by the

Michigan State University, East Lansing, MI 48824.

${ }^{1}$ Department of Horticulture.

${ }^{2}$ College of Natural Science.

${ }^{3}$ To whom reprint requests should be addressed; e-mail: biernbau@msu.edu
ASHS Organic Horticulture Working Group for the purpose of reviewing and discussing development of organic curricula. The development of the Michigan State University Student Organic Farm and our organic curriculum is described in three phases (MSUSOF, 2006). The first 3-year phase from Apr. 1999 to Apr. 2002 covers the initial student discussions and concept planning, and includes year-round baby-leaf salad greens production research. The second 3-year phase from Apr. 2002 to Apr. 2005 covers the startup of a 48 -week CSA marketing plan with 25 memberships in 2003-04 and 50 memberships in 2004-05. During this period a curriculum was developed for student interns and employees in the form of an internship manual. Another objective was bringing current MSU classes to the SOF for 1 - to 2 -h field trip visits so students could experience successful organic agriculture, concepts related to the soil food web and compost, CSA as a method of local direct marketing, and methods of year-round farming involving unheated greenhouses and cold storage of selected vegetable crops. The third 3-year phase has just begun and will include the development of a series of courses to be used for an organic farming certificate program, for bachelor-degree students in a wide variety of majors, and for farmer outreach programs. Our objective is to provide useful information for the initiation of other on-campus student operated, year-round organic gardens or farms and the development of an organic curriculum.

\section{Phase I. Program initiation and concept planning}

In Apr. 1999, members of the Michigan Sustainable Agriculture Network (MSAN), a registered student organization (RSO), called a meeting to discuss student interest in an organic agriculture curriculum and the potential for students to gain farming experience. Discussions continued the following fall and spring semesters, but for most meetings half of the group were new students. The group had diverse interests and it was not possible to reach consensus about how to proceed.

With the start of the Fall 2000 semester, a new RSO called the Student Organic Farm Initiative (SOFI) was formed by many of the students that were also in MSAN. One of the students was a lead organizer and completed an independent study course investigating other student farms in the U.S., looking at possible sites for the farm on our campus, working with students to develop a mission statement, and identifying faculty willing to work with students developing the farm. A second student began investigating other student farms and recruiting additional SOFI members to help. At that time there was limited information available about other student farms. The Rodale Publishing electronic magazine NEWFARM printed a story about student farms (Sayre, 2004) and a directory listing $50+$ student farms around the country

\begin{tabular}{lllc}
\hline $\begin{array}{l}\text { Units } \\
\begin{array}{l}\text { To convert U.S. to SI, } \\
\text { multiply by }\end{array}\end{array}$ & U.S. unit & SI unit & $\begin{array}{l}\text { To convert SI to U.S., } \\
\text { multiply by }\end{array}$ \\
\hline 0.4047 & $\mathrm{acre}(\mathrm{s})$ & $\mathrm{ha}$ & 2.4711 \\
0.0929 & $\mathrm{ft}^{2}$ & $\mathrm{~m}^{2}$ & 10.7639 \\
0.4536 & $\mathrm{lb}$ & $\mathrm{kg}$ & 2.2046
\end{tabular}


with contact information (revised Fall 2005 ) (Sayre, 2005).

As a member of MSAN who had participated in most of the first year meetings, J.A. Biernbaum became the faculty advisor to SOFI and the instructor for the independent study on organic farming. Based on student requests, we initiated a one-credit selected topics course for the Spring 2001 semester to learn more about organic farming.

Several students who were members of SOFI and also L.H. Bailey Scholars (an undergraduate specialization in the College of Agriculture and Natural Resources) attended the first W.K. Kellogg Food and Society Conference in Pittsburgh in Feb. 2001. Between the conference and the end of the spring semester, working with L. Thorp, a fellow L.H. Bailey Scholar and the new director of the Residential Initiative for Study of the Environment (RISE) specialization, two students submitted a concept letter to the new food and society program requesting support to help start the SOF and to demonstrate methods of winter harvesting from unheated greenhouses. Later that summer, we were invited to prepare a full proposal.

During Fall 2001 the students learned about writing a proposal. Other possible sources of funding were investigated to start the farm, which identified the U.S. Department of Agriculture (USDA) Higher Education Challenge Grant Program. During the Spring 2002 semester, our proposal was submitted to the USDA Higher Education Challenge Grant seeking funds to help start the farm and to facilitate current MSU classes visiting the farm. We also completed a proposal to the W.K. Kellogg Foundation that would meet its requirement of demonstrating methods to ensure that the farm would be sustainable. We developed a plan to start a 48 -week CSA that aligned with the semesters (16-week sessions for spring, summer, and fall semesters) and would use results of an existing research program investigating the production of baby-leaf salad greens and other vegetables in unheated greenhouses. The connection to the research was partially based on our study of what made other student farms in the U.S. successful. A connection to research was also encouraged by the W.K. Kel$\operatorname{logg}$ Foundation. From Apr. 2001 to Apr. 2005, approximately $\$ 120,000$ in research and outreach support established the initial site, including construction of the first two greenhouses, allowed the testing and refinement of ideas being used by farmers for winter harvesting of salad greens, provided for outreach to farmers and school gardening programs, and funded a part-time research assistant.

\section{Phase II. CSA startup and on- farm curriculum development}

While the USDA proposal was not funded, the Kellogg proposal $(\$ 95,000)$ was with a start date of 15 Aug. 2002. We started building greenhouses at the site of the winter salad greens research project at the Horticulture Teaching and Research Center on the MSU campus during the fall semester. Three greenhouses were built by students working mostly on Saturdays. In Jan. 2003 the first graduate student farm manager was employed and assumed responsibility for crop scheduling and production based on her previous farming experience. During Spring 2003 we also held a "selected topics" course focused on community supported agriculture.

Students in the course and other SOFI students helped develop crop schedules and plans, start seeds and transplants for the greenhouses, learned about the wide variety of CSA models and identified a specific model, recruited members, and gave presentations to prospective members, all as part of the class. During that time a second winter season of salad greens research was completed and the research assistant (a staff position) taught the new farm manager and students about planting in the greenhouses. Our first distribution of greenhousegrown greens and root crops was the first week of May 2003. This milestone was a major accomplishment and key point in time for our group.

An annotated bibliography of helpful literature and details of the growth of the farm are reported in the farm manager's master of science thesis (Ferrarese, 2005). Facilities descriptions, CSA information, student employment experiences, and other relevant information are included.

Our CSA has three 16-week sessions that align with the semesters. There were 25 memberships the first year and 50 the second year, with a session cost of $\$ 350$. We learned a great deal about CSA and our members' reasons for joining and participating. During Fall 2004 and Spring 2005 we invited our CSA members to form a core group to help with CSA management. We spent several meetings explaining the operation and budget of the SOF to the eight core group members. The core group is helping us to develop a service commitment of $8 \mathrm{~h}$ per session for all members. The purpose of the $8 \mathrm{~h}$ per 16 -week commitment is both to engage members in the activities of the SOF and to support the students.

In Jan. 2003 we also resubmitted a revised proposal to the USDA Higher Education Challenge Grant Program for $\$ 100,000$ to support growth of the farm and a second graduate student employee to focus on coordinating education activities. Key objectives were to demonstrate how students could learn about organic farming during the academic year using the solar greenhouses. We also planned to invite instructors from a wide range of majors to bring their classes to the SOF for field trips and to experience organic farming.

The revised proposal was funded and a second graduate student assistant farm manager and education coordinator was employed in Aug. 2003. The farm was in full production with ample demonstrations to show students visiting the farm. The project was successful with over 400 students visiting the farm in the first year and increasing to over 600 the second year. Numerous presentations were made about the farm in additional classes, one being a human nutrition class of over 750 students. In our second year of instruction in that class, every student received a sample of fresh baby-leaf salad greens and we partnered with a local chef who provided a cooking demonstration in the lecture hall using produce from the farm and a portable stove. Most of the students were quick to come to the front of the lecture hall for a sample.

We also hosted a RISE specialization seminar class at the SOF. Twenty-five students with no previous gardening experience were able to sow seeds in the passive solar greenhouses at the start of fall semester and harvest baby-leaf salad greens and other vegetables through December. They also learned how to make compost and care for the plants. The following semester, the vegetable production class sowed 
seeds in late January and also grew and harvested vegetables through the winter and into spring. With all this hands-on educational activity and the demonstrated interest of the students, we gained recognition from the university administration.

During this time outreach workshops about winter baby-leaf salad greens production were presented in 1 - and 2-d formats with funding support from a North Central Sustainable Agriculture and Research Education project. Farmers as well as members of the Michigan Organic Food and Farm Alliance, and the Michigan Food and Farm Systems came to the farm for tours. Tours also included Master Gardeners and a class for the MSU Evening College. Articles in the campus and local papers as well as in NEWFARM (Sullivan, 2004) helped build a relationship with the organic farming community.

The core group of students worked very hard during these first 2 years. The grant funding and CSA income allowed most to be paid. The half-time assistantship stipend did not fairly compensate the work of the two lead graduate students who managed the farm while also taking classes. The original intent of a "plan A" research thesis was changed to a "plan B" nonresearch program where the "thesis" was a report providing detailed documentation of their work with the SOF in one case (Ferrarese, 2005) and with winter greenhouse gardening at a local elementary school in the other. The non-research plan would have been the appropriate choice from the start.

During the first summer, students, staff, and faculty worked together to identify core values, develop a mission statement, and to narrow our focus to four main goals. The core values are diversity, trust, love, curiosity, awareness, and oneness. The mission is to cultivate a sustainable, community supported student farm. The four goals are to 1 ) practice organic farming methods and maintain annual organic certification; 2 ) expand and refine year-round local food production, harvest, storage and marketing methods; 3 ) increase the diversity of organisms, people, and food on the farm; and 4) develop an experiential learning curriculum for students and people of all ages and learning styles.

We completed the 3-year requirement for transition to organic and submitted our farm plan and certification application during early Summer 2004. As part of a for-credit independent study, an undergraduate student completed the initial research about certification during Fall 2003, presented the information to her fellow students, and then worked on collecting all the information and preparing the farm plan. The inspector from the Organic Growers of Michigan praised the farm and detail of the farm plan. The SOF received organic certification, another historic milestone, and well-earned respect from the Michigan organic farming community.

As part of our research, during the first 2 years, all crops harvested and representative CSA shares were weighed to provide a record of the crops harvested and distributed. In our first year over $22,500 \mathrm{lb}$ of produce were harvested from approximately $10,000 \mathrm{ft}^{2}$ of greenhouse space and 1.5 acres of field production. Approximately $10 \%$ of the harvest was donated to a local food bank. The CSA members received very generous shares because most everything grew well and we had planted extra, assuming some would not. The second year, we had twice as many memberships ( 25 to 50 ) and harvested about $29,000 \mathrm{lb}$ of produce from the greenhouses and 3 acres of field production. The CSA members again received more than was promised or expected.

The research assistant coordinated the data collection. A variety of crops were tested in both single-layer covered greenhouses and double-layer inflated greenhouses, and with either frost fabric or polyethylene as an internal cover. Important temperature and light data were collected. All the students were able to see this research in progress and learn from it.

\section{Phase III. Development of classes}

The SOF grew quickly and the agenda was ambitious for the number of people involved. Everyone involved was much occupied with operating the CSA, maintaining the farm, and supporting related programming. Primarily as paid employees, students were learning the basic processes, but there was not time for detailed teaching or explanation. The students requested classes that would provide the necessary background information. As early as Fall 2003 a plan for courses began to develop and the first draft was included in a Spring 2004 planning session for the Department of Horticulture. The Department of Horticulture approved the plan in Fall 2004 and a proposal to the College of Agriculture and Natural Resources was presented in Feb. 2005.

The new courses were designed as one-credit packages ( $12.5 \mathrm{~h}$ contact) that could double as farmer outreach sessions that could be presented in 2 d. Some of the courses are being developed for online presentation. At MSU, the Institute of Agriculture Technology (IAT, 2006) offers several certificate programs, which were used as models to design this new program.

Funding for course development in 2005-07 is coming from MSU and the USDA Integrated Organic Program grant awarded to MSU in 2005. The first cohort of students will begin Spring 2007 semester. The original plan to start during the fall semester and run for 16 months was changed based on input from a wide range of stakeholder organizations. Starting in January rather than September better aligns with the farming calendar.

The proposed 12-month (January to December) on-campus portion of the "organic farming" certificate program (Table l) will be administered through the Department of Horticulture and the IAT in the College of Agriculture and Natural Resources. The IAT has an application and acceptance procedure independent of the MSU bachelor of science (BS) program. The program will have a minimum entry requirement of a high school diploma and will use 100-, 200-, and 300-level courses open to both BS and IAT students. The focus will be coursework balanced by hands-on growing and operation of the SOF. Students will take at least nine credits of coursework each semester and a two- to four-credit practicum class. The summer session will include a class titled "Study a Farm" to provide field trips to organic farms, and an independent study class to provide the opportunity for a specific focus area selected by the student. Students will be eligible for hourly compensation for non-class related work. To complete the certificate, a supervised internship of 16 weeks on an organic farm or with an urban or community gardening project is required.

A one-credit class is $50 \mathrm{~min}$ per lecture for 15 weeks or $12.5 \mathrm{~h}$. The 
Table 1. Courses planned for the 40-credit year-round organic farming certificate program scheduled to start Spring 2007 semester at Michigan State University.

\begin{tabular}{|c|c|c|}
\hline $\begin{array}{l}\text { Organic farming } \\
\text { (seven courses, seven credits) }\end{array}$ & $\begin{array}{c}\text { Horticulture crops } \\
(\text { eight courses, } 15 \text { credits })^{\mathrm{z}}\end{array}$ & $\begin{array}{c}\text { On farm } \\
\text { (six courses, } 18 \text { credits })\end{array}$ \\
\hline $\begin{array}{l}\text { Organic Farming Principles } \\
\text { and Practices (1) }\end{array}$ & Plant Science (2) & $\begin{array}{l}\text { Student Organic Farm Practicum } \\
\quad \text { Spring }(2)\end{array}$ \\
\hline Organic Soil Management (1) & Vegetable Production and Management (3) & $\begin{array}{l}\text { Student Organic Farm Practicum } \\
\text { Summer (4) }\end{array}$ \\
\hline Compost Production and Use (1) & Fruit Production and Management (3) & $\begin{array}{l}\text { Student Organic Farm Practicum } \\
\text { Fall }(3)\end{array}$ \\
\hline Organic Plant Health Management (1) & $\begin{array}{l}\text { Passive Solar Greenhouses } \\
\quad \text { for Protected Cultivation (1) }\end{array}$ & Independent Study (2) \\
\hline Organic Produce Direct Marketing (1) & Organic Transplant Production (1) & Study a Farm (3) (field trip course) \\
\hline Organic Produce Wholesale Marketing (1) & Specialty Cut Flowers (1) & --- \\
\hline
\end{tabular}

${ }^{2}$ Number of credits are indicated in parentheses.

Department of Horticulture has been testing the concept of making onecredit classes available over 5 weeks, either as three 50 -min or two 75 -min classes per week. Three consecutive classes on different topics are available through the semester at the same time. Students can select one, two, or three of the classes, depending on interest.

The $12.5 \mathrm{~h}$ of contact time works well for a $2-\mathrm{d}$ format. The $2 \mathrm{~d}$ can either be a Friday-Saturday, or can be a weekday and then the same day l week later. The split format has succeeded over the years because students have time to absorb course materials from the first day and come back with more questions 1 week later. The $12.5 \mathrm{~h}$ of material can often be distilled to $1 \mathrm{~d}$ if an audience already has some experience with the topic.

Our goal is to develop materials that can be used for multiple audiences. We started with farmer outreach presentations for some of the topics and these materials are now used for credit classes. Other topics will be developed first for credit and then for outreach presentations.

The SOF is a place to engage students who are not planning on becoming farmers but are more interested in the farm as a place to study environment and food system-related issues. The SOF and RISE connection is being developed so the residential environment students will be able to support the farm by purchasing food and come to the farm and help grow their own food. Students in the RISE program will learn by doing and get the support of the student farmers who check and if necessary maintain greenhouse crops regularly for the RISE students. In return, the RISE students will volunteer to help with large harvesting projects that require additional labor. Farmers supporting the community, the communitysupporting the farmer is a key principle of the curriculum. Since the more than 160 RISE students come from five colleges and 25 majors from thoughout the university, the scope of the program is substantial.

During Fall 2005, an interdisciplinary team of MSU faculty submitted an internal proposal for development of a specialization titled "Sustainable Agriculture and Food Systems" (SAFS) as part of a university initiative to strengthen undergraduate education. A specialization (minor) is typically 15 to 21 credits of courses available to students in a wide range of majors. A key part of the approved funding is for a full-time academic specialist position to coordinate development and management of the program. We envision a curriculum that will complement the organic farming certificate program and that will include a core set of SAFS courses and perhaps some of the organic farming courses.

\section{Conclusions}

One student who has worked at the farm for several years recently shared that when she told her organic farming friends that she was coming to MSU, they questioned why she would attend an institution where they taught people how to use chemicals and pesticides. Now when she shares that she works at MSU with her friends or new acquaintances, they say "Isn't that where they have that great student organic farm?" The Michigan organic farming community is proud of the SOF at MSU-an important step in the right direction. Our goal is that some day they will send their children or employees to MSU.

The SOF has provided a place to integrate organic research, teaching, and outreach. Very little of the applied research is replicated or publishable in peer-reviewed journals yet, but it is research for students to see and participate in so that they value the methods and results. As more faculty become involved, and if space allows, there will be an opportunity for more research and student involvement.

One of the largest challenges to date has been having enough people with farming and people management skills at the SOF to keep the project growing and students learning. Success is primarily attributed to the graduate students and staff involved who highly valued the project goals and the students they were helping. For other schools wishing to emulate our model, we hope that these positive outcomes will be useful to help convince potential financial supporters, including your own university, that the probability of success and the return on investment are worthwhile. Starting the farm with a full-time staff or academic specialist or farm manager position is highly recommended. Undergraduate and graduate students are in a much better position to help either in paid or volunteer positions when there is a paid full-time manager. We continue to work on a model that will be sustainable - not just financially and environmentally 
sustainable, but one where the program does not have to be unreasonably supported by the passionate efforts of a few leaders who go above and beyond the call of duty.

\section{Literature cited}

Bradley, J.C., D. McConnell, M. Kane, and G. Miller. 2003. Development and implementation of a nonmajors horticultural survey class. HortTechnology 13:196-199.

Dyer J.E., L.M. Breja, and R.J. Andreasen. 1999. Attitude of college of agriculture freshmen toward agriculture. J. Agr. Educ. 40:1-10.

Dyer J.E., R. Lacey, and E.W. Osborne.1996. Attitude of University of Illinois College of Agriculture freshmen toward agriculture. J. Agr. Educ. $37: 33-42$.

Ferrarese, M. 2005. It takes a village to make a salad: The development of the Student Organic Farm and Community Supported Agriculture Program at Michigan State University. Paper submitted for the Masters of Science requirement, Michigan State Univ., East Lansing.

Institute of Agriculture Technology. 2006. AgTech: Institute of Agriculture Technology Programs. 24 Mar. 2006. <http://www. canr.msu.edu/agtech/programs.html>.

Michigan State University Student Organic Farm. 2006. MSU Student Organic Farm. 24 Mar. 2006. <http://www.msuorganicfarm.com $/>$.

Newcomb, L.H. 1993. Transforming university programs of agricultural education.J. Agr. Educ. 34:1-10. 24 Mar. 2006. $<$ http://pubs.aged.tamu.edu/jae/pdf/ vol34/34-01-01.pdf>.

Sayre, L. 2004. The NEWFARM: Farming for credit. 24 Mar. 2006. <http://www. newfarm.org/features/0104/studentfar$\mathrm{ms} /$ studentfarms.shtml>.

Sayre, L. 2005. The NEWFARM: A directory of student farms. 24 Mar. 2006. <http://www.newfarm.org/depts/student-farm/directory.shtml>.

St. Hilaire, R. and J.M. Thompson. 2005. Integrating a university and community college course in landscape construction. HortTechnology 15:409-413.

Sullivan, D. 2004. The NEWFARM: Fertile minds. 24 Mar. 2006. <http://www. newfarm.org/features/0804/msu/index. shtml>. 